See discussions, stats, and author profiles for this publication at: https://www.researchgate.net/publication/256035682

\title{
ESL Learners Learning Content Subject in English: What do the Malaysian First Cohort Students Say?
}

Article in International Journal of Learning · January 2012

DOI: $10.18848 / 1447-9494 / C G P / 18107 / 47669$

CITATIONS

2 authors:

Souba Rethinasamy

University Malaysia Sarawak

26 PUBLICATIONS 58 CITATIONS

SEE PROFILE

Some of the authors of this publication are also working on these related projects:

Language Assessment Validation View project

Project Learning Science and Maths in English View project
Kee-Man Chuah

University Malaysia Sarawak

56 PUBLICATIONS 180 CITATIONS

SEE PROFILE 


\section{THE INTERNATIONAL}

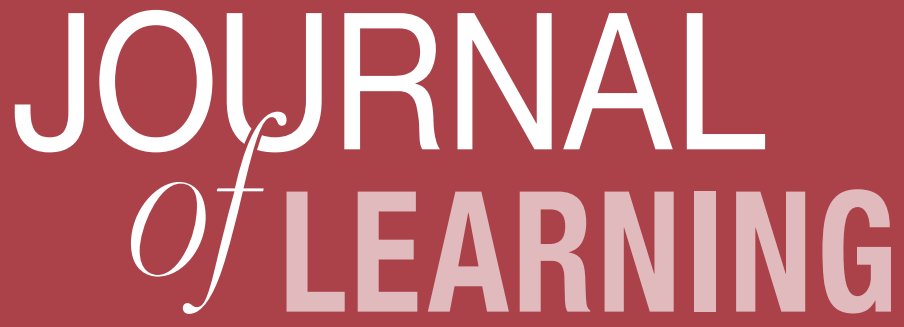

Volume 18, Issue 7

ESL Learners Learning Content Subject in English: What do the Malaysian First Cohort Students Say?

Souba Rethinasamy, Kee Man Chuah and Mohd. Hafizan Hashim 
THE INTERNATIONAL JOURNAL OF LEARNING

http://www.Learning-Journal.com

First published in 2012 in Champaign, Illinois, USA

by Common Ground Publishing LLC

www.CommonGroundPublishing.com

ISSN: $1447-9494$

(C) 2012 (individual papers), the author(s)

(c) 2012 (selection and editorial matter) Common Ground

All rights reserved. Apart from fair dealing for the purposes of study, research, criticism or review as permitted under the applicable copyright legislation, no part of this work may be reproduced by any process without written permission from the publisher. For permissions and other inquiries, please contact

<cg-support@commongroundpublishing.com>.

THE INTERNATIONAL JOURNAL OF LEARNING is peer-reviewed, supported by rigorous processes of criterion-referenced article ranking and qualitative commentary, ensuring that only intellectual work of the greatest substance and highest significance is published.

Typeset in Common Ground Markup Language using CGPublisher multichannel typesetting system

http://www.commongroundpublishing.com/software/ 


\title{
ESL Learners Learning Content Subject in English: What do the Malaysian First Cohort Students Say?
}

\author{
Souba Rethinasamy, Universiti Malaysia Sarawak, Sarawak, Malaysia \\ Kee Man Chuah, Universiti Malaysia Sarawak, Sarawak, Malaysia \\ Mohd. Hafizan Hashim, Universiti Malaysia Sarawak, Sarawak, \\ Malaysia
}

\begin{abstract}
Throughout the world English language has become an important language of academic instruction. Thus, the teaching and learning of a content subject in English is not a unique phenomenon in various parts of the world. In Malaysia, English for the Teaching of Mathematics and Science (ETeMS) policy was implemented in 2003. This has received and is still receiving various reactions particularly from politicians, parents, language experts and policy makers. This study employed a survey research design and investigated the views of the 600 students who have completed all 6 years of primary education under the ETeMS policy. Four aspects of the students' views namely, views on personal ability in English, learning Science in English, importance of learning Science in English and language medium preference were covered in the questionnaire items. The findings show that the majority of the students viewed their English language ability as good, had positive views about learning Science in English, very aware of the importance of learning Science in English and preferred to learn Science in English only and bilingually in the Malay language and English. The paper highlights the need to listen to the students' voice and recommends the way forward for addressing English medium instruction issues.
\end{abstract}

Keywords: English Medium Instruction (EMI), Content Based Learning (CBL), ESL Learners

\section{Background}

7 HE USE OF the English language in various fields has become inevitable and reviews of previous studies have shown that it has become a very noteworthy lingua franca compared to other languages (Halliday, 1998; Ihejieto, 1995; Jenkins, 2007; Lo, 1991; Swain, 1996). Thus, it is not surprising that many countries have adopted English as the medium of instruction in educating their younger generation. Considering English as an important language of power and employability (Din et al., 2003; Pennington, 1991), children are exposed to the English language as early as possible. In most countries, the medium of instruction is made based on political reasons rather than educational grounds (Choong, 2004; Ong, 2006; Rollnick, 2000).

In the $21^{\text {st }}$ century, society has given more attention towards science and technology-based subjects. Most courses in the university especially science-based courses are highly dependent on references or materials that are published in the English language (Lillis, Hewings, Vladimirou, \& Curry, 2010; Hyland, 2006). Hence, it was felt that it was a good exposure for the students to be exposed to study subject matters in English as their preparation for the future study. In recent years, the emergence of English as a medium of instruction in the 